\title{
Participatory Identification of Major Natural Resource Constraints and Potentials Under Koka-Lewate Watershed, Tembaro Woreda, Kambata Tambaro Zone of Southern Ethiopia
}

\author{
Dawit Kanito \\ Natural Resource Management Directorate, Southern Agricultural Research Institute, Areka Agricultural Research Center, Areka, Ethiopia \\ Email address: \\ dawitkanito.skm@gmail.com

\section{To cite this article:} \\ Dawit Kanito. Participatory Identification of Major Natural Resource Constraints and Potentials Under Koka-Lewate Watershed, Tembaro \\ Woreda, Kambata Tambaro Zone of Southern Ethiopia. International Journal of Energy and Environmental Science. \\ Vol. 5, No. 1, 2020, pp. 1-6. doi: 10.11648/j.ijees.20200501.11
}

Received: January 8, 2020; Accepted: February 24, 2020; Published: March 31, 2020

\begin{abstract}
Koka-Lewate watershed is located in the Tambaro district of Southern Ethiopia and it is about $328 \mathrm{~km}$ and $185 \mathrm{~km}$ far from Addis Ababa and Hawassa respectively. It was selected by a virtual team (team of researchers from a natural resource, crop science, livestock, and socioeconomic departments) organized from Areka Agricultural Research Center, Southern Agricultural Research Institute (SARI). It was selected for its high level of degradation, minimal intervention and high amount of sediment load contribution on the Gibe III hydroelectric power dam. This study aimed to identify and prioritize natural resource constraints of the watershed and to document reports as baseline information for comparison after project implementation. Data for this study were collected from primary and secondary sources. The study catchment is characterized by intensive. The study revealed, soil erosion is severe and caused damage to house, inputs, and farmland fragmentation. Human and livestock damaged by a flood during the heavy storm were also reported. Intensive rainfall in combination with steep slope cultivation, lack of fallowing and deforestation were the prime causes of soil erosion. Soil fertility degradation is the major crop production constraint of the catchment which accounts for $97.9 \%$. Mainly it is devastated by soil erosion, lack of fallowing, and intensive cultivation. The result shows that topography, skill gap, and inaccessibility of technology limited irrigation practice in the watershed. Furthermore, forest resources are deteriorating at an alarming rate owing to rapid population growth and agricultural land expansion.
\end{abstract}

Keywords: Watershed, Natural Resources, Soil and Water Conservation, Small Scale Irrigation, Soil fertility, Koka-Lewate

\section{Introduction}

The natural resource includes all resources that exist in a natural state and all systems that are or can be useful to the man in the actual technological, economical and social circumstances [1]. It is a glorious gift and has enormous and vital importance to community livelihood. Natural resource degradation in general and soil erosion, in particular, is the major challenge of the South Nation Nationalities Peoples' Region (SNNPR) [2]. Unwise management and use of natural resources are one of the major socio-economic and environmental factors that caused low crop yield in SNNPR. Among the natural resources; land, soil, forest, and water are the major dominant ones that play a vital role in the food security status of households. But, now a day due to the rapidly growing population and demand, it is under demolishment. Individual agricultural land loss is increasing and has become an acute problem as a result of the alarmingly growing population. The negative impacts of land shortage have to lead to lower food production, soil fertility decline, environmental degradation, reduce conservation of nature, and constrained food price and nutrition [3 4]. Moreover, land quality has become extremely low due to overutilization, mismanagement, and erosion. The total regional population of the SNNPR is reported to be 14929548 , which covers $7 \%$ of the total population of the country [5]. The same report reveals that Kambata-Tambaro 
is one of the most populous zones of the region having 490.54 persons per square kilometer.

Rapid population growth has caused people to expand into marginal hilly areas, increasing soil and water loss, and depletion of resources, biodiversity loss, and destroying of natural habitat $[6,7]$. As a result, mostly natural resources management has left many problems unresolved, including natural resource use conflicts, negative trans boundary interactions among neighboring farms and villages, and the absence of collective action in addressing common concerns. Besides, degradation of common property resources such as communal grazing land, community forest and woodland, wetland, water body and associated biodiversity [8]. These challenges could be solved by implementing the concept of participatory integrated watershed management. The importance of watersheds as ecological units in the context of natural resource management has a vital role. Watershed is a hydrologic unit that is often used as biophysical and socioeconomic or political units for the planning and management of natural resources [9]. Participatory watershed management may be defined as a process whereby users define problems and priorities, set criteria for sustainable management, evaluate possible solutions, implement programs, and monitor and evaluate impacts [10]. Koka-Lewate watershed has been selected by virtual teams organized from the Southern Agricultural Research Institute (SARI) for its high level of degradation and minimal intervention. Besides, Koka-Lewate is part of Gilgel Gibe catchment that significantly yields in a high amount of sediment load that directly joins the Gibe III hydroelectric power dam. The sheet erosion of Gibe catchment contributes about $4.47 \times 10^{7}$ ton/year and hence $2210 \mathrm{ton} / \mathrm{km}^{2}$ [11]. As a result, SARI is intended to put a memorial fingerprint on Gibe III hydroelectric power dam by conducting different researchbased development activities to improve and rehabilitate natural resources.

Therefore, to ensure effective implementation of the project, a comprehensive survey with farmers and key stakeholders was held to identify existing potentials and constraints of natural resources in Koka-Lewate watershed by researchers from various backgrounds. Besides, this report will be used as baseline information to compare the impact of the project after an intervention.

\section{Methodology}

\subsection{Description and Location Map of the Study Area}

Koka-Lewate micro-watershed is found in Tembaro Woreda, Kembata Tembaro Zone of Southern Ethiopia. It is found to the east of the Omo River and is $328 \mathrm{~km}$ far from Addis Ababa to the south and $185 \mathrm{~km}$ from Hawassa. Geographically it is located between $338649 \mathrm{~m}-338926 \mathrm{~m} \mathrm{~N}$ latitude and between $799087 \mathrm{~m}-802310 \mathrm{~m}$ E longitudes. The elevation in the watershed area ranges from 1320 to 2052 mals. The total area of the watershed is estimated to be 567.13 ha and incorporate two Kebeles namely Bohe and Bachira. It has 302 household heads and from those 264 is male and 38 are female $\mathrm{HH}$.

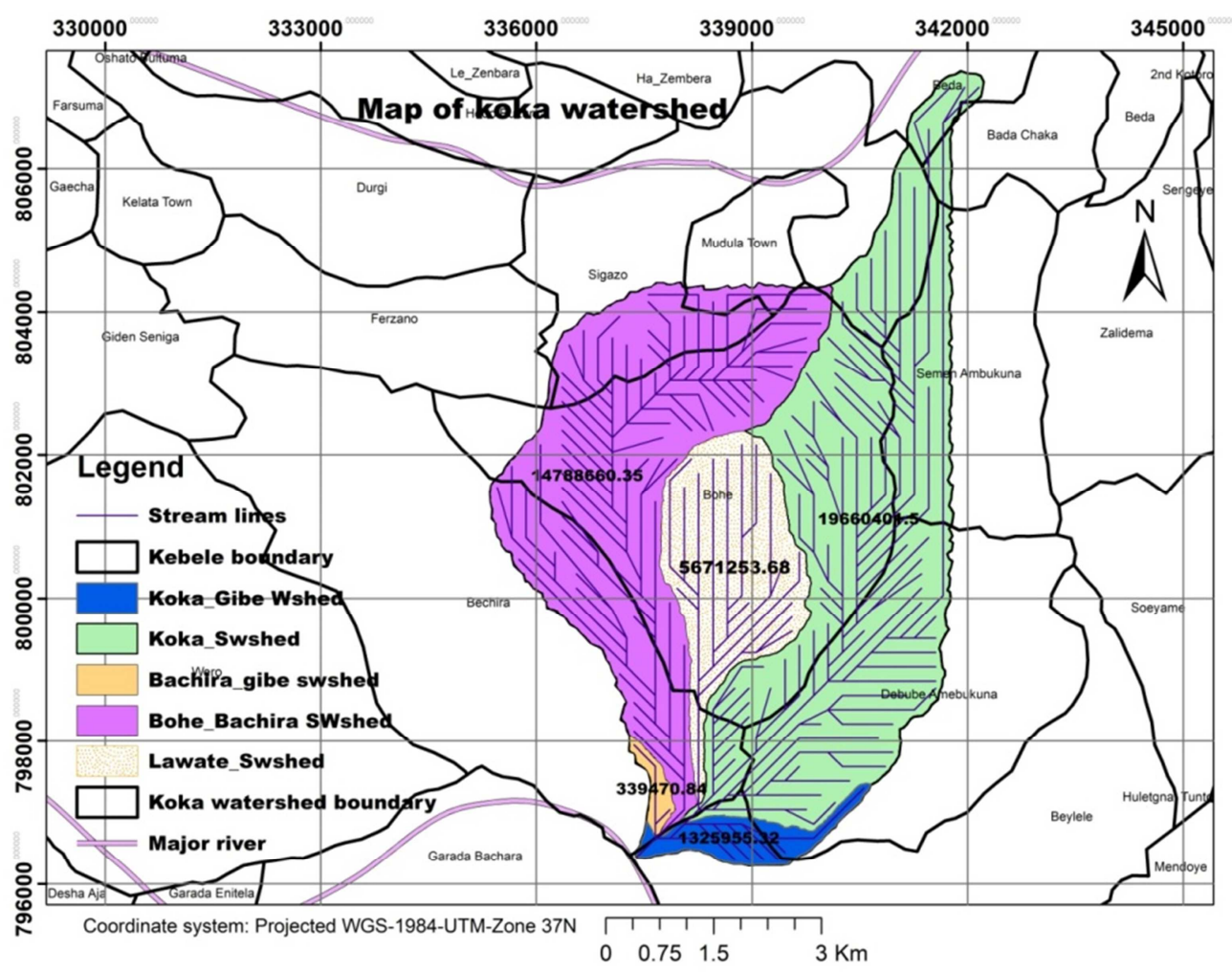

Figure 1. Location Map of the study area (Source: field survey/GPS, 2017). 


\subsection{Method of Data Collection and Analysis}

Data for this study was obtained from both primary and secondary sources. The primary data were collected from qualitative and quantitative sources. The primary data was also acquired from key informant interview and focus group discussion at the district and peasant association level; transect observation, and formal and informal interview. To held formal interviews; 47 households (HH) head farmers were randomly selected and interviewed from the total area of the watershed. From those, 34 were male-headed and 13 were female-headed. Secondary data was obtained from District Agriculture and Natural Resource Development Office mainly from official documents. Finally, a team of researchers from various disciplines were employed in biophysical characterization of an entire catchment to triangulate and confirm the problem stated by respondents.

Data were analyzed by SPSS for Windows Version 20 to prepare statistical results in the quantitative and qualitative ways of expression [12]. Besides, the pairwise ranking was employed to prioritize the problems addressed. Tables, figures and graphs were used for the presentation of the findings.

\section{Results and Discussion}

\subsection{Land Use}

The study result revealed the watershed is intensively cultivated. From the total catchment area, the proportion of land use of respondents is about $34.36,4.89,0.77$, and 3.18 ha cultivated, grazing, outcrop, and woodland respectively. The study indicated, there is land shortage per $\mathrm{HH}$ and most farmers under study area engaged in converting forest and fragile lands to cultivated land particularly at downstream of the catchment. All respondents dictated the study area has a history of a dense forest; however, due to deforestation and agricultural land expansion, it is seriously devastating. The result shows, deforestation, intensive cultivation, and agricultural expansion to fragile lands are the main factor contributing to accelerated soil erosion, land degradation, migration of wild animals, a hindrance to production and productivity.

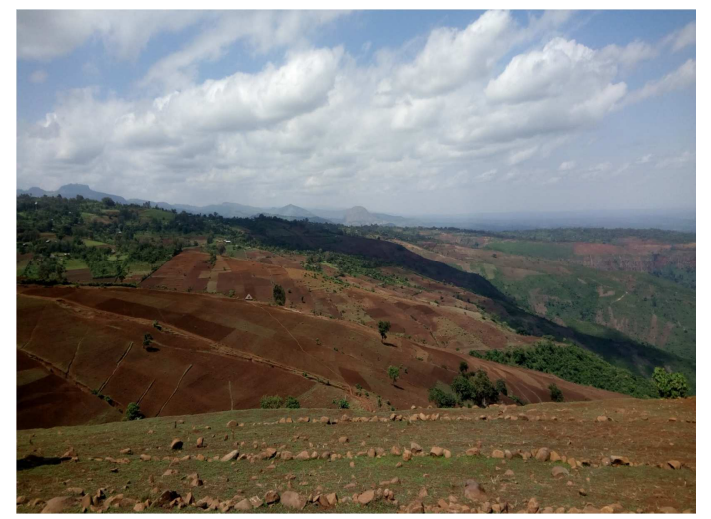

Figure 2. Dominant land use type of the study area (Source; field survey, 2017).

\subsection{Soil Erosion and Management}

Soil erosion is a significant environmental problem affecting agricultural productivity of study catchment. Discussion held with farmers and extension agents revealed that due to undulated topography, cultivation of steep slope and marginal lands, intensive rainfall with erratic nature, free grazing, and deforestation; soil erosion frequently occurs in the watershed. From field observation, researchers perceived that sheet and rill erosion which are caused by intensive rainfall coupled with cultivation of sloppy and marginal lands are dominant types of soil erosion in the area. In some parts of the catchment, deeper and wider gullies were also observed. Farmers were well acquainted with the negative impact of soil erosion on their lives. They pointed out that, the level of erosion is severe and caused several hazardous. Among these, damage to the house, damage to crops and fertilizers, road break, farmland fragmentation, drought and drying of spring are common ones. Damage on animals and humans by flood during a heavy rainstorm is also reported. Severe downstream siltation and deposition were identified as soil erosion problems in the study area. Shortly, this may pose a harsh impact on Gibe III hydroelectric power dam [13]. Although soil erosion has a severing effect, the use of physical conservation measures are not carried out by farmers' initiative but initiated by government organizations. As a result, constructed conservation structures failed to serve the planned reason. Besides, inappropriate design, wrong structure selection, and construction, damage by heavy runoff, human activities and animal (grazing), lack of follow-up and maintenance are observed problems under study catchment. As cited by respondents, currently the soil needs extra inputs and labor to provide them satisfactory products because of fertility degradation caused by soil erosion. Respondents also reported workable soil depth is decreasing year to year.

Table 1. Causes of soil erosion.

\begin{tabular}{lllll}
\hline No. & Causes & $\begin{array}{l}\text { Frequency } \\
(\mathbf{N = 4 7 )}\end{array}$ & $\begin{array}{l}\text { Percent } \\
(\%)\end{array}$ & Rank \\
\hline 1 & Intensive rainfall (short time) & 47 & 100 & $1^{\text {st }}$ \\
2 & $\begin{array}{l}\text { The steep slope and marginal } \\
\text { land cultivation }\end{array}$ & 40 & 85.1 & $2^{\text {nd }}$ \\
3 & Lack of fallowing & 39 & 83 & $3^{\text {rd }}$ \\
4 & Overgrazing & 32 & 68.1 & $4^{\text {th }}$ \\
5 & Deforestation & 15 & 31.9 & $5^{\text {th }}$ \\
6 & $\begin{array}{l}\text { Sense of poor ownership } \\
\text { Miscellaneous (road break, }\end{array}$ & 5 & 10.6 & $6^{\text {th }}$ \\
7 & $\begin{array}{l}\text { badly designed furrow and } \\
\text { cutoff drains) }\end{array}$ & 4 & 8.5 & $7^{\text {th }}$ \\
\hline
\end{tabular}

Source:-Field survey (2017).

The study revealed that, to date, conversion of forest into cropland has become very common and led to increased vulnerability to soil erosion. Expansion of agricultural lands on sloppy land without conservation practices is also reported as a cause for soil erosion. Less integration of soil and water conservation practices with agroforestry practices is also 
another problem.

The finding depicts that, indicators of soil erosion perceived by farmers were formation of rills and gully, poor in crop and grass growth, change in soil color, roots and subsoil exposure, difficult of land preparation, and sediment deposition at depressions $97.9 \%, 83 \%, 72.3 \%, 63.8 \%, 44.7 \%$, and $34 \%$ respectively. Almost all respondents were aware of soil erosion impact on the food security of their household.

The study revealed, most of the respondents are familiar with the impact of soil erosion and its severity level. About $74.5 \%, 23.4 \%$, and $2.1 \%$ of the respondents dictated the severity level of erosion in the study area is high, medium and low respectively. To reduce the effect of soil erosion, $95.7 \%$ of the respondents were implementing soil and water conservation measures through a massive community based participatory watershed development and productive safety net programs. On another hand, a limited number of respondents $4.3 \%$ were not implementing soil and water conservation measures due to the awareness gap, land shortage, labor intensive, and lack of access to equipment [14, 15].

Farmers manage soil erosion problems using both physical and biological conservation measures. Tree plantation, plantation of banana and desho grass, contour plowing, soil bund, stone bund, fanya juu terrace, and cutoff drain are common in the area. Experts revealed that the use of biological conservation measures is very limited in type and area coverage. In general, lack of adequate and effective soil and water conservation measures coupled with poor management of the existing conservation measures have led the problem of soil erosion to continue.
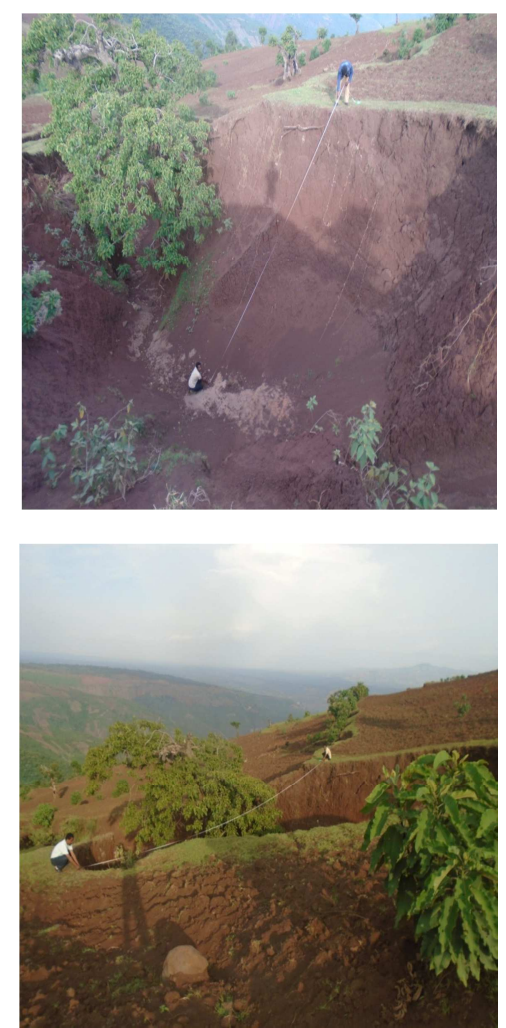

Figure 3. Soil erosion and land degradation under Koka-Lewater watershed (Source; field survey, 2017).

\subsection{Soil fertility and Its Management}

A decline in soil fertility is a common problem in the study area that hinders crop productivity. Almost all farmers confirmed that the fertility level of their land is decreasing year by year and farmers reported that soil fertility degradation as a serious problem. Respondents perceive that soil erosion $(95.7 \%)$, lack of fallowing $(85.1 \%)$, intensive cultivation (83\%), and absence and/or low inorganic fertilizer application (59.6\%) is the main driving force for soil fertility degradation [16]. Only about $40.4 \%$ and $31.9 \%$ of respondents were reported on the absence of crop rotation and absence and/or low organic fertilizer application respectively were the causes of fertility decline. Lack of knowledge and use of biofertilizer, inadequate experience to intercropping and mulching have been accelerating soil fertility problems in the study area. Farmers, experts, and development agents reported that lack of integrated conservation measures, removal of crop residue, plowing of steep slopes and deforestation as a major factor for soil fertility degradation.

Almost all respondents have good acquaintances on a decrease in yield and performance of crops and grasses were the major indicators of soil fertility degradation. In the study area, farmers are taking various measures to improve and maintain the fertility status of their farm (Table 2).

Table 2. Major crop production constraints.

\begin{tabular}{lllll}
\hline No & Problems & $\begin{array}{l}\text { Frequency } \\
(\mathbf{n = 4 7 )}\end{array}$ & $\begin{array}{l}\text { Percent } \\
(\mathbf{\%})\end{array}$ & Rank \\
\hline 1 & Soil fertility degradation & 46 & 97.9 & $1^{\text {st }}$ \\
2 & Soil erosion & 44 & 93.6 & $2^{\text {nd }}$ \\
3 & Acidity & 14 & 29.8 & $3^{\text {rd }}$ \\
4 & Management gap & 18 & 38.3 & $4^{\text {th }}$ \\
\hline
\end{tabular}

Source:-field survey (2017).

Farmers and experts reported various constraints related to soil fertility management. The problems include a lack of information on the magnitude of soil acidity and lack of amelioration options. Another common production problem reported by the respondents was the lack of different soil fertility management. Particularly, inorganic fertilizer recommendation (types and rate) for each major crop was highly reported. Usually, farmers use a blanket or below the blanket recommendation and they apply similar amounts and types of fertilizers for almost all crops regardless of the requirement. Farmers also mentioned the high price of commercial fertilizer frequently since the current price is not affordable by poor farmers. Additionally, soil conservation and restoration measure were also limited that exacerbate topsoil loss.

Farmers in study catchment have been practicing different soil fertility management measures. During the focus group discussion and household survey farmers explained that they used Urea, NPS, and NPSB. They also reported that they use organic sources (farmyard manure and compost) to enhance soil fertility and are common practice. But, due to labor intensiveness and large quantity needed per unit square, they 
use organic sources only for homestead crops.

Table 3. Measures take on to enhance crop yield and yield components in order of their merit.

\begin{tabular}{lllll}
\hline No & Measure & $\begin{array}{l}\text { Frequency } \\
(\mathbf{n = 4 7 )}\end{array}$ & $\begin{array}{l}\text { Percent } \\
\mathbf{( \% )}\end{array}$ & Rank \\
\hline 1 & Inorganic fertilizer & 21 & 44.7 & $1^{\text {st }}$ \\
2 & Compost & 10 & 21.3 & $2^{\text {nd }}$ \\
3 & Farm yard manure & 7 & 14.9 & $3^{\text {rd }}$ \\
4 & SWC measures & 5 & 10.6 & $4^{\text {th }}$ \\
5 & Crop rotation & 3 & 6.4 & $5^{\text {th }}$ \\
6 & Land fallowing & 1 & 2.1 & $6^{\text {th }}$ \\
\hline
\end{tabular}

Source:-field survey (2017).

\subsection{Small Scale Irrigation and Water Availability}

Surface and groundwater potential is insignificant and limited. The topography of the watershed is undulated and rivers are located in the middle of the valleys making traditional irrigation difficult. According to experts, there is no modern irrigation practicing in the study catchment. The only water sources in the study area are springs and rivers dominantly used as livestock water points and household consumptions. As dictated by respondents, existing water source has a problem like far off from their home, the presence of worms, and seasonal drying. Respondents were listed the name of rivers get dried during their age; named as, Bara, Lewate, Bude, and Wawarsa. Additionally, farmers also listed the name of dried springs like Wokase, Yele, Zerede, and Kepizoda. They pointed out that climate change, sediment deposition, and land degradation were driving forces for the drying of the water points. Though they face a water resource problem, there is no water harvesting structure constructed yet. In general, major constraints of irrigation are topography/landscape, lack of skill, lack of motor pumps, lack of modern irrigation schemes and irrigation technologies.

\subsection{Forestry and Agroforestry Practices}

However, there was no well-developed agroforestry practice in the study area; traditionally farmers practice the homestead agroforestry system. The result depicts that, farmers rarely incorporate and manage woody species in farmlands deliberately. Gravelle robusta, Ficus sur, Cordia Africana, and Erythrina species are commonly planted trees as an agroforestry system. In most cases, this system is not integrated with introduced in situ soil and water conservation measures and experiences poor management. The study showed that the system also includes fruit tree species such as Persea Americana, Mangifera indica, Coffee Arabica, Ensete ventricosum, and Musa species. As reported by key informants and focus group discussion, the watershed has a history of dense natural forest at lower section in particular. It consists of various multipurpose woody species such as Albizia gummifera, Vernonia amygdalina, Acacia species, Juniperus procera, Cordia Africana, Ficus sur, Ricinus communis, and Jacaranda mimosifolia. Plantation forest dominantly includes Eucalyptus species, Grevillea robusta,
Juniperus procera, and Cupressus lusitanica.

The result revealed that natural vegetation cover have been deteriorating from time to time at shocking rates and are under severe pressure because of several factors. Crop land (for ginger production) expansion at the cost natural vegetation seems to be the number one reason for deforestation in the area [17]. The other major factors stated by farmers and experts are charcoal production, fuelwood, construction material, timber and awareness gap in the order of their magnitude. Additionally, due to free grazing, the survival of planted seedlings was reported to be a major problem. Recently, climate change, disease, and pests have become notable setbacks of forest products in the study catchment.

Farmers and development agents stated that the major problems related to the agroforestry system are lack of supply of improved varieties of fruit trees. Besides, the lack of introduction and promotion of multi-purpose trees and insufficient supply of tree seeds are major problems related to agroforestry development in the area.

The study showed that farmers deliberately plant trees and shrub species on farmland, home gardens, and degraded lands because they are important sources of food, energy, fodder, and construction materials. Besides, the respondent's belief that species like Ricinus communis can improve soil fertility and others are also important to reduce soil erosion.

\section{Conclusion and Recommendation}

Based on the result obtained from focus group discussion and field observation, soil erosion and soil fertility degradation were the major setbacks of Koka-Lewate watershed. The occurrence of frequent droughts due to low and erratic rainfall poses high agricultural production risks leading to food insecurity. Farmers are unable to produce crops using irrigation during the dry season. Also, rapid deforestation of forest resources with limited provision of improved varieties of fruit trees and a poorly developed agroforestry system was noted. Based on the finding of this study, the following recommendations are forwarded: integrated watershed-based soil and water conservation measures, site and crop-specific fertilizer recommendation, introduction of modern irrigation schemes and irrigation technologies, provision of improved varieties and management practice on multipurpose forestry and agroforestry practices besides awareness creation among farmers under catchment is paramount important.

\section{Acknowledgements}

This study was made possible by financial and technical support provided by Southern Agricultural Research Institute (SARI). I would also like to extend my appreciation to $\mathrm{Mr}$. Abiy G/Michael for his assistance in the watershed delineations and technical support he provided to enrich the paper. 


\section{References}

[1] Flavin C., 2002 - Starea lumii (The world state), Edit. Tehnică, Bucureşti, Romania.

[2] Tsegaye G. and G/michael A., 2014. Review on the overall status of soil and water conservation system and its constraint in different agroecology of Southern Ethiopia. Journal of Natural Sciences Research (ISSN), 4 (7): 2224-3186.

[3] Raheldum M. (2013). Causes and consequences of Agricultural land losses of Rajshahi District, Bangladesh. IOSR Journal of Environmental Science, 5 (6): 58-65.

[4] Lal, R. (2015). Restoring soil quality to mitigate soil degradation. Sustainabiltiy (Switzerland), 7 (5), 5875-5895.

[5] Central Statistical Agency: The 2007 Population and Housing Census of Ethiopia: Statistical Report for Southern Nations, Nationalities and Peoples' Region; Part I: Population Size and Characteristics. July 2010.

[6] Kalipeni, Ezekiel. (1992). Population Growth and Environmental Degradation. Africa insight. 22. 273-82.

[7] Mittal, Rahul. (2013). Impact of Population Explosion on Environment. Weschool Knowledge builder - the national journal.

[8] German L., Kidane B., and Mekonnen K., 2005. Watershed Management to Counter Farming Systems Decline: Toward a Demand-Driven, Systems-Oriented Research Agenda. Agricultural Research \& Extension Work, 145.

[9] Brooks, N. K., P. F. Folliot and J. L. Thames, 1991. Watershed Management: A Global Perspective, Hydrology and the
Management of Watersheds. Ames, Iowa: Iowa State University Press pp 1-7.

[10] Johnson, N. L., H. M. Ravnborg, O. Westermann and K. Probst, 2001. User Participation in Watershed Management and Research. Water Policy, 3: 507-520.

[11] Devi, R.; Tesfahune, E.; Legesse, W.; Deboch, B.; Beyene, A. Assessment of siltation and nutrient enrichment of Gilgel Gibe dam, Southwest Ethiopia. Bioresour. Technol. 2008, 99, 975979.

[12] IBM, 2011. IBM SPSS IBM SPSS Statistics 20 Core System User's Guide IBM Corporation 1989 (2011).

[13] Wolancho, K. W., 2012. Watershed management: an option to sustain dam and reservoir function in Ethiopia. J. Environ. Sci. Technol. 5 (5), 262-273.

[14] Tesfaye, G. (2019). Evaluating Technical Standards of Implemented Soil and Water Conservation Technologies in Jimma Zone, Soouth-West Ethiopia. Agricultural Research \& Technology: Open Access Journal, 19 (4).

[15] Wolka, K., Sterk, G., Biazin, B., \& Negash, M. (2018). Benefits, limitations and sustainability of soil and water conservation structures in Omo-Gibe basin, Southwest Ethiopia. Land Use Policy, 73 (December 2016), 1-10.

[16] Odendo, M., Obare., \& Salasya, B. (2010). Farmers' perceptions and knowledge of soil fertility degradation in two constraining sites in western Kenya. Land Degradation Development, 21 (6), 557-564. https://doi.org/10.1002/ldr.996.

[17] Amsalu, A., Stroosnijder, L,. \& Graaff, J. de. (2007). Longterm dynamics in land resource use and the driving forces in the Beressa watershed, highlands of Ethiopia. Journal of Environmental Management, 83 (4), 448-459. 